\title{
Characterization and Phylogeny of Fungi from Industrial Wastewater Using Highly Conserved Multiple Gene Loci
}

\author{
Blessing Amaka Ezeonuegbu ( $\sim$ amakaezeonu@gmail.com ) \\ Ahmadu Bello University \\ Dauda Abdullahi Machido \\ Ahmadu Bello University \\ Clement Z. Whong \\ Ahmadu Bello University \\ Wisdom S. Japhet \\ Ahmadu Bello University \\ Clement Ameh Yaro \\ University of Uyo \\ Gaber El-Saber Batiha \\ Damanhour University
}

Research Article

Keywords: Fungi, ITS, Beta tubulin, Calmodulin, RPB2, PCR, Phylogeny

Posted Date: March 18th, 2021

DOI: https://doi.org/10.21203/rs.3.rs-289731/v1

License: (1) (i) This work is licensed under a Creative Commons Attribution 4.0 International License. Read Full License 


\section{Abstract}

The aim of this study was isolation and molecular characterization of fungi from untreated industrial effluent by multigene phylogenetic analyses. The Fungi isolated were characterized based on PCR amplification and genomic sequencing of the internal transcribed spacer region (ITS), partial $\beta$-tubulin (Ben A), calmodulin (CaM), and DNA-directed RNA polymerase second large subunit (RPB2) genes, along with morphological characterization and species diversity. Fungal DNA extraction kits and primers sets for the selected genes were purchased and used following the manufacturer's instructions. The obtained sequences were subjected to BLAST analysis and the corresponding fungal isolates were assigned species names after comparison with representative sequences available in GenBank. All the sequences from this study were deposited in GenBank and the accession number assigned. Phylogenetic trees of the fungal isolates were drawn for each gene by the Maximum Likelihood method using MEGA 7.0 software. Fifteen (15) Fungi species belonging to four genera of Aspergillus, Penicillium, Fusarium and Trichoderma with Aspergillus as the predominant genus were identified.

\section{Introduction}

Fungi are diverse group of eukaryotic organisms characterized as heterotrophic, saprophytic, symbiotic and parasitic due to their achlorophyllous nature. Their cell walls are made up of $\beta$-glucans and chitin (Manoharachary et al., 2010). They are known as the second largest after kingdom Animalia with estimate of over 5 million species (Raja et al., 2017). The kingdom fungi is composed of nine phyla mamely; Opisthosporidia, Chytridiomycota, Neocallimastigomycota, Blastocladiomycota, Zoopagomycota, Mucoromycota, Glomeromycota, Basidiomycota and Ascomycota (Simeos et al., 2015; Yakop et al., 2019). The Ascomycota or sac fungi, are monophyletic and account for approximately $75 \%$ of all described fungi. Generally, fungi are significant both economically and medicinally as they are the major decomposers of dead organic matter and contribute significantly in recycling of nutrients in natural and modified ecosystems. They are also found in edible forms, producers of antibiotics, cheese formers and few of them are pathogenic.

Apart from known enormous importance of Fungi, the taxonomy of these organisms is still challenging due to a lack of reliable and advanced techniques for their identification and systematic studies. Morphological or conventional approaches to fungal systematics have some difficulties in determining species boundaries as these techniques of identification rely primarily on phenotypic analysis. For instance they describe colour, texture, spores, colony size and utilization of carbon and nitrogen compounds (Das et al., 2014). Thus other characteristics are needed for identification to species level. Gene sequence based identification of fungi has many advantages over the conventional methods as it does not require viable organisms or sporulation. In order to resolve the difficulties on identification at species level, many advanced techniques have been employed for the identification of fungi with emphasis on house-keeping genes and other target genes through the use of PCR and automated sequencing techniques.

Few of the several genetic markers for rapid classification of fungi having conserved sequences falling within definite microbial clades include internal transcribed spacer regions (ITS), Beta-tubulin genes (Ben A), Calmodulin (CaM) and RNA polymerase II gene (RPB2) (Das et al., 2014; Raja et al., 2017; Yin et al., 2017; Rajeshkumar et al., 2019).

The internal transcribed spacer regions (ITS) are used as official universal DNA barcode for fungi (Das et al., 2014; Yin et al., 2017). The ITS1, ITS2, and ITS4 have been proven to be useful for the identification of yeasts and some fungi such Aspergillus, Penicillium, Talaromyces, Cryptococcus, candida and Trichosporon among many others (Adeniyi et al., 2018; Rajeshkumar et al., 2019; Yin et al., 2017). However, ITS sequences cannot be used for phylogenetic analyses of unrelated taxa due to low variability and slow evolution. Also, ITS sequences do not always allow correct species differentiation especially among Aspergillus and Penicillium genera (Houbraken \& Samson, 2011; Visagie et al., 2014). Hence, additional gene markers are essential for correct species delineation. Secondary molecular markers such as beta tubulin; calmodulin and RPB2 have been successfully used in fungal genomics (Kolanlarli et al., 2019; Raja et al., 2017; Rajeshkumar et al., 2019; Visagie et al., 2014). Asan et al., 2011 reported that these protein-encoding genes contained highly variable intron regions which contain highly variable introns that evolve at a faster rate compared to ITS.

Beta-tubulin genes are found in all eukaryotes encoding for polypeptide proteins. They have been used for phylogenetic analysis in fungi from the entire kingdom to the species level. Four Beta tubulin genes are found in all fungi; two a-tubulin (tub A) and two $\beta$ - 
tubulin (tub B) genes. Tub A is responsible for the production of two alpha tubulin polypeptides (alpha 1 and alpha 2) while Tub B produces one alpha polypeptide (alpha 2) (Das et al., 2014). Reports have it that beta-tubulin gene sequences contain 3.5-fold more phylogenetic information than the small sub-unit (SSU) rRNA gene, thus it has been reported that it is an ideal marker for analysis of deep-level phylogenies and for complex species groups (Raja et al., 2017; Visagie et al., 2014).

Calmodulin (CaM) is a small acidic protein present in all eukaryotic cells and shown to be highly conserved both functionally and structurally (De Carvalho et al., 2003; De Cássia et al., 2001). Its primary role is to serve as an intracellular $\mathrm{Ca}^{2+}$ receptor which signals proliferation, motility, and cell cyclic progression. $\mathrm{Ca}^{2+}-\mathrm{CaM}$ complexes act by controlling the activity of numerous intracellular proteins such as phosphodiesterase, $\mathrm{Ca}^{2+}$-ATPase, serine protein kinases, and protein phosphatases. It also acts on several metabolic pathways and gene expression regulation in many eukaryotic organisms including fungi (De Carvalho et al., 2003).

Transcription of the eukaryotic nuclear DNA into RNA is carried out by RNA polymerases using ribonucleoside triphosphates as substrates (Gerber et al., 2020; Malkus et al., 2006). RNA polymerase Il gene (RPB2) encodes for second largest protein subunit in eukaryotes which synthesizes mRNA precursors and functional non-coding RNAs (Malkus et al., 2006). Vetrovsky et al. (2015) reported that RPB2 gene is a viable alternative molecular marker for the analysis of environmental fungal communities due its discriminative power, quantitative representation of community composition and suitability for phylogenetic analyses. Therefore this study was aimed at isolation and molecular identification of fungi from waste water using the selected molecular markers discussed.

\section{Materials And Methods}

\subsection{Collection of untreated refinery effluents}

Samples of untreated effluent were collected from waste water channel of Kaduna Refinery and Petrochemical Company (KRPC), Kaduna State, Nigeria. The samples were collected in ten-litre new plastic jerry cans and transported to the laboratory for physicochemical, heavy metal analysis and biosorption studies. The $\mathrm{pH}$ and temperature of the effluent were determined at the point of collection.

\subsection{Isolation and molecular characterization of test fungi from untreated refinery effluent}

\subsubsection{Isolation of fungi from untreated waste water}

The effluent samples collected were kept to stand at room temperature $\left(30^{\circ} \mathrm{C}\right)$ on a sterile laboratory work bench. $10 \mathrm{ml}$ of the samples in duplicates were aseptically dispensed in sterile centrifuge tubes and centrifuged at a speed of 250rpm for 10minutes to concentrate the samples. After decanting the supernatant, $0.1 \mathrm{ml}$ of the residue of each sample was spread-plated on sterile potato dextrose agar and Malt Extract Agar (MEA) plates in duplicate (containing 50 $\mathrm{g} / \mathrm{L}$ of chloramphenicol) using sterile bent glass rod. The plates were incubated at room temperature for 7 days.

\subsubsection{Colony morphology and microscopic characterization of fungal Isolates}

Colonies grown on each medium were distinguished on the basis of their surface characteristics such as texture, colour, zonation, sporulation and diameters. The distinguishable colonies were sub-cultured on PDA slant and incubated at room temperature $\left(25^{\circ} \mathrm{C}\right)$ for 7 days to obtain pure isolates. The microscopic characteristics were carried out by mounting small portion of the growing region 
of the fungi on a clean grease free slide with a drop of lacto phenol cotton blue, covered with a cover slip and examined under electron microscope using $\times 40$ objective lens. The isolates were characterized on the basis of the sexual reproductive structures, presence or absence of septation, presence of foot cells and chlamydospores. The isolates were identified using taxonomic guide (Barnett and Hunter; 1999; Hakeem and Bhatnagar 2011; Asan et al., 2011). The pure cultures were maintained in PDA slants and stored in refrigerator for further identification.

\subsubsection{Molecular identification of fungal isolates}

\subsubsection{Extraction of fungal genomic DNA}

Each of the isolates was grown on potato dextrose agar at room temperature $\left(25^{\circ} \mathrm{C}\right)$ for 5 days. This was followed by sub-culturing each isolates into a $250 \mathrm{~mL}$ Erlenmeyer flask containing $100 \mathrm{~mL}$ potato dextrose broth and incubating for 5 days. The mycelial mass produced by each isolate were separated from the broth by filtration through sterile No. 5 Whatman filter paper. The mycelial mass were crushed using porcelain mortar and transferred to Eppendorf tubes for extraction.

The genomic DNA extraction was carried out using ZR Fungal/Bacterial DNA MiniPrep Kit (Zymo Research, Irvine, CA, USA) according to manufacturer's manual instructions. (Viegas et al., 2015; Khandavilli et al., 2016; Yin et al., 2017; Adeniyi et al., 2018).

\subsubsection{PCR amplification of the target genes}

Primers specific for internal transcribed spacer region (ITS), beta-tubulin gene (benA), calmodulin gene (CaM) and RNA polymerase II second largest subunit (RPB2) loci are presented in Table 1.

PCR amplification of the extracted DNA was performed in a $20 \mu \mathrm{L}$ reaction mixture as follow: $1 \mu \mathrm{L}$ gDNA template, $0.2 \mu \mathrm{L}$ DNA polymerase, $0.5 \mu \mathrm{L}$ each forward and reverse primers, $1 \mu \mathrm{L}$ dNTPs and sterile double distilled water to a final volume of $20 \mu \mathrm{L}$.

The thermocycler was programed for the following PCR conditions: initial denaturation at $94{ }^{\circ} \mathrm{C}$ for 5 min, 35 cycles of denaturation at $94^{\circ} \mathrm{C}$ for $45 \mathrm{~s}$, annealing at $55^{\circ} \mathrm{C}$ for $45 \mathrm{~s}$, and extension at $72{ }^{\circ} \mathrm{C}$ for $1 \mathrm{~min}$, with a final extension at $72{ }^{\circ} \mathrm{C}$ for 10 min. For the amplification of RPB2 gene region, touch-up PCR conditions of 5 cycles with annealing temperature $48^{\circ} \mathrm{C}$ followed by 5 cycles at $50{ }^{\circ} \mathrm{C}$ and final 25 cycles at $52^{\circ} \mathrm{C}$ were used. After complete amplification, the PCR products were analyzed for gel electrophoresis by using $1 \%$ agarose gel ( $1 \mathrm{~g}$ of agarose in $100 \mathrm{ml}$ of Tris buffer) with ethidium bromide as the staining agent (Houbraken \& Samson, 2011).

\subsection{Sequencing and phylogenetic analysis}

The fungal isolates were identified by DNA sequencing according to standard protocols. Sequencing was carried out in a $28 \mu \mathrm{l}$ reaction mixture as follows: $4 \mu$ l of each primer, $8 \mu$ l of purified DNA and $16 \mu$ l of PCR water and the samples was sequenced with the Di- Deoxy Terminator sequencer. The contigs (formed from forward and reverse sequences) obtained were analyzed using BioEdit 7.2.5 software and aligned using Clustal W of MEGA 7.0 software (Goujon et al., 2010; Kumar et al. 2015; Yin et al., 2017). The corresponding fungal isolates were assigned species names after comparison with representative sequences available in NCBI 
(National Center for Biotechnology Information). The newly obtained sequences were deposited in GenBank and accession number assigned.

The evolutionary history of the fungi was analyzed using the Maximum Likelihood (ML) method based on the Tamura-Nei model of MEGA 7 (Kumar et al. 2015; Sidiq et al., 2016). The bootstrap tree formed from 1000 replicates represents the evolutionary history of the taxa analyzed The percentage associated taxa clustered together in the bootstrap test (1 000 replicates) is shown next to the branches (Houbraken et al., 2010)

\section{Results And Discussions}

\subsection{Cultural and microscopic characteristics of fungal isolates}

Fifteen (15) fungal isolates consisting of four genera; Aspergillus, Penicillium, Fusarium and Trichoderma were obtained in this study with Aspergillus being the predominant genera (Table 2, Figures 1a and 1b). The results revealed the cultural features of the isolates (F1 to F23) in terms of colour, surface characteristics, reverse, edge and diameter. The microscopic features of the isolates are presented in Figures 2(a) and 2(b) showing the conidia, spores and conidiophores. Aspergillus species had septate hyphae, hyaline conidiophores and radial conidial head bearing the spores (Figure 2a). Penicillium species appeared as septate hyphae with conidiophores and secondary branches (metulae). The metulae bear flasked shaped phialides with unbranched chains of round conidia (Figure 2b). Fusarium spp showed septate hyphae, multiseptate canoe shaped macroconidia attached to the conidiophores (Figure 2b). Trichoderma spp appeared as septate hyphae, short conidiophores which are flask shaped clustering together at the end of each phialides (Figure $2 b$ ).

The genus Aspergillus is one of the most well researched fungi genera with over 200 officially recognized species (Oyebanji et al., 2018). The ubiquitous nature of Aspergillus may be due to their saprophytic feeding habit as well as their ability to grow in a wide range of environment (Machido et al., 2014). This observation sturdily indicates that members of these fungal genera isolated, have the capacity to survive and withstand toxic effects of polycyclic aromatic hydrocarbons (Ezeonuegbu et al., 2014).

\subsection{Polymerase Chain Reaction (PCR) of fungal isolates obtained}

The fungal isolates from this study were further subjected to molecular identification, by amplifying the internal transcribed spacer (ITS), beta tubulin gene (Ben A), calmodulin gene (CMD) and RNA Polymerase II Second Largest Subunit (RPB2) genes of the fungal isolates (Figures 3-6).

\subsubsection{Amplification of internal transcribed spacer}

Thirteen out of the fifteen isolates were positive to PCR amplification of ITS regions with amplicon sizes of 600 base pairs (Figure 3). Aspergillus niger (F3) and P. simplicissimum (F23) represented by lanes 4 and 16 respectively were negative. Although, the ITS region is widely used as universal primers for fungi, it is not sufficient for identifying most fungi to specie level due to their low variability and slow evolution (Houbraken \& Samson, 2011; Tiwari et al., 2011). Visagie et al. (2014) however suggested the use of other molecular markers for accurate identification of fungal species and phylogenetic relationships. Other secondary identification markers for Aspergillus and Penicillium species (and other ascomycetes) used in this study were beta tubulin; calmodulin and RPB2. These protein-encoding genes contained highly variable intron regions (Asan et al., 2017; Ozdil et al., 2017; Yin et al., 2017).

\subsubsection{Amplification of beta-tubulin gene}

Page 5/22 
Amplification of the beta tubulin gene revealed isolates represented by lanes $2,4,7,10,12$ respectively were positive with amplicon sizes of 600 base pairs (Figure 4). Isolates represented by lanes 3, 5 and 15 respectively had amplicon sizes of approximately $550 \mathrm{bp}$. Also, isolates represented by lanes $9,11,14$ and 16 respectively had amplicon sizes of 500bp. Fungi represented by lanes 6 , 8 and 13 respectively were negative (Figure 4 ).

Amplification of the partial beta-tubulin gene was successful in thirteen isolates (13) out of the fifteen (15) isolates amplified. The amplicon sizes obtained were in the range of $480-600 \mathrm{bp}$. This results were similar to those obtained in previous studies. For instance, Ashtiani et al., (2017), Eulalia et al. (2018) and Kamarudin \& Zakaria, (2018) who amplified Aspergillus fragments of beta tubulin genes with amplicon sizes in the range of 550 to $600 \mathrm{bp}$. Samson et al. (2014) and Erika et al. (2012), obtained beta tubulin gene amplicon sizes of ranging from 432 to $550 \mathrm{bp}$ for Aspergillus, Penicillium and other fungal species. Beta-tubulin genes are found reliably in all eukaryotes and have been used for phylogenetic analysis in fungi from the entire kingdom to the species level. It is an ideal marker for analysis of deep-level phylogenies and for complex species groups. Reports have shown that beta tubulin genes have more resolution compared to the ITS region. This amount of variation is suitable for phylogenetic relationship among closely related species of Penicillium and Aspergillus species (Asan et al., 2019; Samson et al., 2014).

\subsubsection{Amplification of RPB2 gene}

The amplified partial RPB2 genes of the isolates revealed that only two isolates, $P$. citrinum (F19) and P. citrinum (F19D) represented by lanes 5 and 7 were positive with amplicon sizes of approximately 650 and 600 base pairs respectively (Figure 5). This result is in agreement with the studies of Houbraken \& Samson, (2011) who identified Penicillium citrinum using RPB2 genes.

\subsubsection{Amplification of Calmodulin gene}

The result of the amplified calmodulin genes of the isolates showed that $A$. niger (F5), A. niger (F10) and P. citrinum (F19) represented by lanes 5, 9 and 15 had sizes of 500bp, 550 bp and 500bp respectively (Figure 6).

The calmodulin gene has been considered important for the identification of Aspergillus species, and some reports have even stated it should be used as the primary gene for identification of Aspergillus species (Ashtiani et al., 2017; Samson et al., 2014).

\subsection{Gene Sequences of Fungal Isolates}

The identifications based on cultural features were confirmed by sequence analysis of the isolates. Basic Logical Alignment Search Tool (BLAST) results of ITS region, Beta-tubulin, RPB2 gene and calmodulin gene sequences of this study in National Center for Biotechnology Information (NCBI) provided indications of possible relationships and similarities with reference sequences in GenBank. The amplified sequences of each gene were submitted to GenBank, and their accession numbers are shown in Table 3 which revealed that most isolates had above $95 \%$ similar identity to reference sequences of GenBank.

There has been little or no extensive research on identification of the Fungi using different molecular marker approach in Nigeria. Focus has been more on macroscopic and microscopic features. 
Phylogenetic trees of the fungal isolates revealed that the isolates were clustered in grouping pattern of close resemblance. The percentage of trees in which the associated taxa are clustered is shown next to the branches. Sequences from this study are shown in red colours while sequences from GenBank are shown in black. Test of phylogeny was bootstrap of 1000 replications. Phylogenetic tree based on ITS gene revealed that the alignment matrix contained 54 nucleotide sequences with 209 positions in the final dataset. All isolates of Aspergillus and Penicillium species were clustered with ex-type strains from Genbank with cluster identity of above $95 \%$. The tree was out grouped by T. erinaceum (Figure 7).

Beta-tubulin gene alignment matrix contained 52 nucleotide sequences with with 19 positions in the final dataset. All the fungal species had above $85 \%$ cluster similarity with ex-type from GenBank while P. simplicissimum was placed in the out group (Figure 8).

Phylogenetic tree based on partial RPB2 gene revealed that the alignment matrix involved 19 nucleotide sequences with a total of 404 positions in the final dataset. The two positive isolates of Penicillium citrinum shared $90 \%$ cluster similarities with sequences from GenBank (Figure 9).

Phylogenetic tree based on calmodulin gene had an alignment matrix of 14 sequences. A. niger (F5D) shared $87 \%$ cluster similarity while the two isolates of $A$. sydowii (F7 and F7D) had equal (98\%) cluster similarities with sequences from GenBank. A. niger (F5) falls in the outgroup (Figure 10). The phylogenetic trees revealed that related species are clustered together indicating a clear and well resolved classification and evolutionary history of the isolates (Asan et al., 2019; Kamarudin \& Zakaria, 2018; Ozdil et a, 2017).

\section{Conclusion}

1. There has been little or no extensive research on identification of the Fungi using different molecular marker approach in Nigeria. Focus has been more on cultural and microscopic features. The fungal isolates from this study were further subjected to PCR amplification coupled with DNA sequencing of four molecular genes markers.

2. The fungal species isolated consist of the following genera; Aspergillus, Penicillium, Fusarium and Trichoderma with Aspergillus being the predominant genera. Sequence results obtained revealed above $95 \%$ similarities between the isolates in this study and those found in GenBank.

3. The identification and molecular characterization of the fungal isolates to specie level, gave a better results by PCR amplification and sequencing of ITS region, partial beta tubulin, calmodulin and RPB2 genes. Therefore should be used as molecular markers for species level identification of fungi (especially Aspergillus and Penicillium as proved by this study).

\section{Declarations}

\section{Conflict of interest}

The authors declare that they have no competing financial interests or personal relationships that could have influence the work reported in this paper.

\section{Acknowledgement}

The authors wish to express their profound appreciations to management of African Bioscience Limited and International Institute of Tropical Agriculture (IITA) Ibadan, Nigeria for their guidance and contributions in conducting the molecular research.

\section{References}

Adeniyi, M., Titilawo, Y., Oluduro, A., Odeyemi, O., Nakin, M., \& Okoh, A. I. (2018). Molecular identification of some wild Nigerian mushrooms using internal transcribed spacer: polymerase chain reaction. AMB Express, 8(148):1-9.

https://doi.org/10.1186/s13568-018-0661-9

Page $7 / 22$ 
Asan, A., Kolanlarli, T. K., Sen, B., \& Okten, S. (2019). Biodiversity of Penicillium species isolated from Edirne S öğü tlük Forest soil ( Turkey ). Nisan, 10(1), 26-39.

Ashtiani, N. M., Kachuei, R., Yalfani, R., \& Harchegani, A. B. (2017). Identification of Aspergillus sections Flavi , Nigri , and Fumigati and their differentiation using specific primers. Le Infezioni in Medicina, 2:127-132.

Barnett, H.L. \& B.B. Hunter. (1999). Illustrated genera of imperfect fungi. Fourth edition. Prentice Hall Inc.

Machido, D.A., Ezeonuegbu, B.A. \& Yakubu, S.E. (2015). Capacity of isolates of six genera of filamentous fungi to remove lead, nickel and cadmium from refinery effluent. International Journal of Innovative Research and Advanced Studies, 2(6):27-31. www.ijiras.com.

Das, S., Dash, H. R., Mangwani, N., Chakraborty, J., \& Kumari, S. (2014). Understanding molecular identification and polyphasic taxonomic approaches for genetic relatedness and phylogenetic relationships of microorganisms. Journal of Microbiological Methods, 103: 80-100. https://doi.org/10.1016/j.mimet.2014.05.013.

De Carvalho, M. J. A., Jesuino, R. S. A., Daher, B. S., Silva-Pereira, I., De Freitas, S. M., Soares, C. M. A., \& Felipe, M. S. S. (2003). Functional and genetic characterization of calmodulin from the dimorphic and pathogenic fungus Paracoccidioides brasiliensis. Fungal Genetics and Biology, 39(3):204-210. https://doi.org/10.1016/S1087-1845(03)00044-6

De Cassia Garcia Simao, R., \& Gomes, S. L. (2001). Structure, expression, and functional analysis of the gene coding for calmodulin in the chytridiomycete Blastocladiella emersonii. Journal of Bacteriology, 183(7):2280-2288.

https://doi.org/10.1128/JB.183.7.2280-2288.2001.

Erika, A.W., Vivian, B., Claudia, C. and Jorge, F.G. (2012). Biodegradation of phenol in static cultures by Penicillium chrysogenum EK1: catalytic abilities and residual photo toxicity. Revista Argentina de microbiologia Vol 44(2).

Eulalia, M.M., Agnieszka, F., \& Zalewska, E.D. (2018). Aspergillus penicillioides Speg. Implicated in Keratomycosis. Polish Journal of Microbiology, 67(4):407-416.

Gerber, A., Ito, K., Chu, C.N. and Roeder, R.G. (2020). Induced RPB1 depletion reveals a direct gene-specific control of RNA Polymerase III function by RNA Polymerase II. Molecular cell, volume 78, issue 4, P765-778.E7.

DOI:https://doi.org/10.1016/j.molcel.2020.03.023. 
Goujon, M.; McWilliam, H.; Li, W.; Valentin, F.; Squizzato, S.; Paern, J. \& Lopez, R. (2010). A new bioinformatics analysis tools framework at EMBL_EBI. Nucleic Acids Research, 38: W695-W699.

Hakeem, A.S. \& Bhatnagar, B. (2010). Heavy metal reduction of pulp and paper mill effluent by indigenous microbes. Asian Journal Experimental Biology Science, 1: 203.

Houbraken, J, \& Samson, R. A. (2011). Phylogeny of Penicillium and the segregation of Trichocomaceae into three families. Studies in Mycology, 70:1-51. https://doi.org/10.3114/sim.2011.70.01

Houbraken, Jos, Frisvad, J. C., \& Samson, R. A. (2010). Sex in Penicillium series Roqueforti. IMA FUNGUS, 1(2):171-180.

Kamarudin, N. A., \& Zakaria, L. (2018). Characterization of two xerophilic Aspergillus spp. from peanuts (Arachis hypogaea) Nur. Malaysian Journal of Microbiology, 14: 41-48.

Khandavilli, R., Meena, R., \& Bd, S. (2016). Fungal phylogenetic diversity in estuarine sediments of Gautami. Current Research in Environmental \& Applied Mycology, 6(4):268-276. https://doi.org/10.5943/cream/6/4/4.

Kumar S, Stecher G \& Tamura K. (2015) - MEGA 7: Molecular Evolutionary Genetics Analysis version 7.0 for bigger datasets. Molecular Biology and Evolution.

Machido, D.A., Ezeonuegbu, B.A. \& Yakubu S.E. (2014). Resistance to some Heavy Metals among Fungal Flora of Raw Refinery Effluent. Journal of Applied Sciences and Environmental Management, 18(4):623-627. https://doi.org/10.4314/jasem.v18i4.10.

Malkus, A; Chang, P.F., Zuzga, S.M, Chung, K.R., Shao, J., Cunfer, B.M., Arseniuk, E. \& Ueng, P.P. (2006). RNA polymerase II gene (RPB2) encoding the second largest protein subunit in Phaeosphaeria nodorum and P. avenaria. Mycological Research, 110 (10):1152-64.

Manoharachary, C., Kunwar, I.K., Reddy, S.V. (2010). Biodiversity, phylogeny and evolution of fungi. In: Sharma V.P. (eds). Nature at Work: Ongoing Saga of Evolution, Springer, New Delhi. https://doi.org/10.1007/978-81-8489-992-4_10.

Oyebanji, E. O., Adekunle, A. A., Coker, H. A. B., \& Adebami, G. E. (2018). Mycotic loads ' determination of non -sterile pharmaceuticals in lagos state and $16 \mathrm{~s}$ rdna identification of the fungal isolates. Journal of Applied Pharmaceutical Research, 6(2):16-28. https://doi.org/10.18231/2348-0335.2018.0007 
Ozdil, S., Asan, A., Sen B. \& Okten S. (2017). Biodiversity of Airborne Fungi in the Indoor Environment of Refrigerators Used in Houses. Journal of Fungus, 8(2):109-124. https://doi.org/10.15318/fungus.2017.41

Raja, H. A., Miller, A. N., Pearce, C. J., \& Oberlies, N. H. (2017). Fungal Identification Using Molecular Tools: A Primer for the Natural Products Research Community. Journal of Natural Products, 80:756-770. https://doi.org/10.1021/acs.jnatprod.6b01085.

Rajeshkumar, K. C., Yilmaz, N., \& Marathe, S. D. (2019). Morphology and multigene phylogeny of Talaromyces amyrossmaniae, a new synnematous species belonging to the section Trachyspermi from India. Mycokeys, 45: 41-56.

https://doi.org/10.3897/mycokeys.45.32549

Samson, R. A., Visagie, C. M., Houbraken, J., Hubka, V., Perrone, G., Seifert, K. A., Susca, A., Szigeti, G., Yaguchi, T., Frisvad, J. C., Tanney, J. B., Varga, J., \& Kocsub, S. (2014). Phylogeny, identification and nomenclature of the genus Aspergillus. Studies in Mycology, 78:141-173. https://doi.org/10.1016/j.simyco.2014.07.004

Sidiq, F., Hoostal, M., \& Rogers, S. O. (2016). Rapid identification of fungi in culture - negative clinical blood and respiratory samples by DNA sequence analyses. BMC Research Notes, 9(293):1-8. https://doi.org/10.1186/s13104-016-2097-0

Simeos, M.F., Ottoni, C. A., Amini, M. S., Alam, I., Alzubaidy, H., Mokhtar, N., Archer, J. A. C., \& Bajic, V. B. (2015). Soil and Rhizosphere Associated Fungi in Gray Mangroves ( Avicennia marina) from the Red Sea - A Metagenomic Approach. Genomics Proteomics Bioinformatics, 13: 310-320. https://doi.org/10.1016/j.gpb.2015.07.002

Vetrovsky, T., Kolarik, M., Zifcakova, L., Zelenka, T. \& Baldrian, P. (2015). The rpb2 gene represents a viable alternative molecular marker for the analysis of environmental fungal communities, Molecular Ecology Resource, 16(2):388-

401.https://doi.org/10.1111/1755-0998.12456.

Viegas, C., Sabino, R., Botelho, D., Santos, M., \& Gomes, A. Q. (2015). complex in cork industry using complementing methods. Arhiv za Higijenu Rada. i Toksikologiju, 66:203-207. https://doi.org/10.1515/aiht-2015-66-2614

Visagie, C. M., Houbraken, J., Frisvad, J. C., Hong, S., Klaassen, C. H. W., Perrone, G., Seifert, K. A., Varga, J., Yaguchi, T., \& Samson, R. A. (2014). Studies in Mycology. Studies in Mycology, 78:343-371. https://doi.org/10.1016/j.simyco.2014.09.001

Yakop, F., Taha, H., \& Shivanand, P. (2019). Isolation of fungi from various habitats and their possible bioremediation. Current Science, 116(5), 733-740.

Yin, G., Zhang, Y., Pennerman, K. K., Wu, G., \& Hua, S. S. T. (2017). Characterization of Blue Mold Penicillium Species isolated from stored fruits using multiple highly conserved loci. Journal of Fungi, 3(12), 1-10. https://doi.org/10.3390/jof3010012

Page $10 / 22$ 


\section{Tables}

Table 1: Primers used for the amplification of specific genes in the fungal isolates

\begin{tabular}{|c|c|c|c|c|c|}
\hline Locus & Primer & Direction & $\begin{array}{l}\text { Oligonucleotide Sequence } \\
\left(5^{\prime}-3^{\prime}\right)\end{array}$ & $\begin{array}{l}\text { Length } \\
\text { (bp) }\end{array}$ & Reference \\
\hline \multirow{4}{*}{$\begin{array}{l}\text { Internal Transcribed } \\
\text { Spacer (ITS) }\end{array}$} & \multirow{4}{*}{$\begin{array}{l}\text { ITS1 } \\
\text { ITS4 }\end{array}$} & \multirow{4}{*}{$\begin{array}{l}\text { Forward } \\
\text { Reverse }\end{array}$} & \multirow{4}{*}{$\begin{array}{l}\text { TCC GTA GGT GAA CCT } \\
\text { GCG G } \\
\text { TCC TCC GCT TAT TGA } \\
\text { TAT GC }\end{array}$} & \multirow[t]{4}{*}{600} & White et al. 1990 \\
\hline & & & & & (Houbraken \& \\
\hline & & & & & \\
\hline & & & & & (Yin et al., 2017) \\
\hline \multirow[t]{3}{*}{$\beta$-tubulin (BenA) } & & & \multirow{3}{*}{$\begin{array}{l}\text { GGT AAC CAA ATC GGT } \\
\text { GCT GCT TTC } \\
\text { ACC CTC AGT GTA GTG } \\
\text { ACC CTT GGC }\end{array}$} & \multirow[t]{3}{*}{550} & $\begin{array}{l}\text { (Houbraken et al., } \\
2010 \text { ) }\end{array}$ \\
\hline & DLCO & neverse & & & $\begin{array}{l}\text { (Houbraken \& } \\
\text { Samson, 2011) }\end{array}$ \\
\hline & & & & & (Yin et al., 2017) \\
\hline \multirow[t]{2}{*}{ Calmodulin (CaM) } & CMD5 & Forward & \multirow{2}{*}{$\begin{array}{l}\text { CCG AGT ACA AGG ARG } \\
\text { CCT TC } \\
\text { CCG ATR GAG GTC ATR } \\
\text { ACG TGG }\end{array}$} & \multirow[t]{2}{*}{580} & $\begin{array}{l}\text { (Houbraken \& } \\
\text { Samson. 2011) }\end{array}$ \\
\hline & CMD 6 & Reverse & & & (Yin et al., 2017) \\
\hline \multirow[t]{3}{*}{$\begin{array}{l}\text { RNA polymerase II second largest } \\
\text { subunit (RPB2-1) }\end{array}$} & $5 F$ & Forward & $\begin{array}{l}\text { GAY GAY MGW GAT CAY } \\
\text { TTY GG }\end{array}$ & \multirow[t]{3}{*}{700} & $\begin{array}{l}\text { (Houbraken et al., } \\
2010 \text { ) }\end{array}$ \\
\hline & ( & nevelae & \multirow[t]{2}{*}{$\begin{array}{l}\text { CCC ATR GCT TGY TTR } \\
\text { CCC AT }\end{array}$} & & $\begin{array}{l}\text { (Houbraken \& } \\
\text { Samson, 2011) }\end{array}$ \\
\hline & & & & & (Yin et al., 2017) \\
\hline
\end{tabular}

Table 2: Cultural characteristics of fungal isolates from untreated refinery effluent 


\begin{tabular}{|c|c|c|c|c|c|c|}
\hline $\begin{array}{l}\text { Isolate } \\
\text { Code }\end{array}$ & Colour & $\begin{array}{l}\text { Surface } \\
\text { characteristics }\end{array}$ & Edge & $\begin{array}{l}\text { Reverse } \\
\text { colour }\end{array}$ & $\begin{array}{l}\text { Colony diameter } \\
\mathrm{mm}) \\
(\mathrm{mean} \pm \mathrm{SD})\end{array}$ & Identity of isolates \\
\hline F1 & mint green & powdery & white, circular & cream & $0.75 \pm 0.21$ & Aspergillus flavus \\
\hline F2 & Black & granular & white, irregular & cream & $2.50 \pm 1.02$ & Aspergillus japonicus \\
\hline F3 & $\begin{array}{l}\text { brownish- } \\
\text { black }\end{array}$ & black & grey, irregular & black & $2.70 \pm 0.14$ & Aspergillus niger \\
\hline F5 & Black & granular & black, irregular & cream & $1.90 \pm 1.02$ & Aspergillus niger \\
\hline F6 & pale pink & granular & $\begin{array}{l}\text { light pink, } \\
\text { irregular }\end{array}$ & white & $2.35 \pm 0.07$ & Aspergillus melleus \\
\hline F7 & dark-green & cottony & white, irregular & white & $1.35 \pm 0.14$ & Aspergillus sydowii \\
\hline F8 & White & smooth & white, circular & cream & $1.20 \pm 0.28$ & Fusarium incarnatum \\
\hline F10 & black & granular & white, irregular & cream & $2.80 \pm 0.97$ & Aspergillus niger \\
\hline F12 & whitish gray & smooth & white, circular & cream & $0.90 \pm 0.00$ & Penicillium shearii \\
\hline F13 & $\begin{array}{l}\text { whitish- } \\
\text { green }\end{array}$ & granular & circular & white & $8.00 \pm 0.00$ & $\begin{array}{l}\text { Trichoderma } \\
\text { erinaceum }\end{array}$ \\
\hline F14 & white & smooth & white irregular & cream & $1.80 \pm 0.00$ & $\begin{array}{l}\text { Aspergillus } \\
\text { quadrilineatus }\end{array}$ \\
\hline F16 & $\begin{array}{l}\text { greenish } \\
\text { blue }\end{array}$ & smooth & white, circular & white & $1.15 \pm 0.07$ & Aspergillus fumigatus \\
\hline F18 & white & cottony & white, irregular & cream & $1.85 \pm 0.07$ & Aspergillus sydowii \\
\hline F19 & bluish-green & cottony & white, irregular & white & $1.30 \pm 0.00$ & Penicillium citrinum \\
\hline F23 & Dark green & cottony & white, irregular & white & $1.25 \pm 0.07$ & $\begin{array}{l}\text { Penicillium } \\
\text { simplicissimum }\end{array}$ \\
\hline
\end{tabular}

Table 3. Accession numbers of amplified nucleotide sequences from fungal. Isolates 


\begin{tabular}{|c|c|c|c|c|c|c|c|c|c|}
\hline \multirow[t]{2}{*}{ Fungi } & \multirow[t]{2}{*}{ Isolate } & \multicolumn{2}{|l|}{ ITS } & \multicolumn{2}{|c|}{ Beta-tubulin } & \multicolumn{2}{|c|}{ Calmodulin } & \multicolumn{2}{|l|}{ RPB2 } \\
\hline & & $\begin{array}{l}\text { Identity } \\
(\%)\end{array}$ & $\begin{array}{l}\text { Accession } \\
\text { No. }\end{array}$ & $\begin{array}{l}\text { Identity } \\
(\%)\end{array}$ & $\begin{array}{l}\text { Accession } \\
\text { No. }\end{array}$ & $\begin{array}{l}\text { Identity } \\
\text { (\%) }\end{array}$ & $\begin{array}{l}\text { Accession } \\
\text { No. }\end{array}$ & $\begin{array}{l}\text { Identity } \\
(\%)\end{array}$ & $\begin{array}{l}\text { Accession } \\
\text { No. }\end{array}$ \\
\hline $\begin{array}{l}\text { Aspergillus } \\
\text { flavus }\end{array}$ & $\mathrm{F} 1$ & 96.89 & MK828704 & 100 & $\mathrm{MH} 180047$ & - & - & - & - \\
\hline A. flavus & F1D & - & - & 100 & MG517775 & - & - & - & - \\
\hline A. japonicus & $\mathrm{F} 2$ & 99.11 & MK840963 & 100 & MH208743 & - & - & - & - \\
\hline A. japonicus & F2D & 97.53 & MK840964 & - & - & - & - & - & - \\
\hline A. niger & F3 & 100 & MK828713 & 99.79 & HQ632731 & - & - & - & - \\
\hline A. niger & F3D & - & - & 100 & MH781323 & - & - & - & - \\
\hline A. niger & F5 & 98.99 & MK840965 & 100 & MH781323 & 98.48 & JX500080 & - & - \\
\hline A. niger & F5D & 97.75 & MK840966 & 99.59 & LC389053 & 98.87 & MG991517 & - & - \\
\hline A. melleus & F6 & 96.71 & MK840967 & - & - & - & - & - & - \\
\hline A. sydowii & F7 & 98.95 & MK828705 & 100 & MH426599 & 96.86 & LN898812 & - & - \\
\hline A. sydowii & F7D & 99.45 & MK828710 & 100 & MH644075 & 96.63 & LN898808 & - & - \\
\hline $\begin{array}{l}\text { Fusarium } \\
\text { incarnatum }\end{array}$ & F8 & - & - & 98.83 & KT374271 & - & - & - & - \\
\hline F. incarnatum & F8D & - & - & 98.90 & KJ020856 & - & - & - & - \\
\hline A. niger & F10 & 99.41 & MK828708 & 100 & MH781319 & - & - & - & - \\
\hline A. niger & F10D & - & - & 100 & MH208814 & - & - & - & - \\
\hline A. fumigatus & F11 & 99.27 & MK816855 & - & - & - & - & - & - \\
\hline $\begin{array}{l}\text { Penicillium } \\
\text { shearii }\end{array}$ & F12 & 98.96 & MK840968 & - & - & - & - & - & - \\
\hline P. shearii & F12D & 95.83 & MK828709 & - & - & - & - & - & - \\
\hline T. erinaceum & F13 & 98.53 & MK840969 & - & - & - & - & - & - \\
\hline $\begin{array}{l}\text { A. } \\
\text { quadrilineatus }\end{array}$ & F14 & 97.98 & MK840970 & - & - & - & - & - & - \\
\hline A. fumigatus & F16 & - & - & 100 & MH781343 & - & - & - & - \\
\hline A.fumigatus & F16D & - & - & 100 & MH781334 & - & - & - & - \\
\hline A. sydowii & F18 & 99.41 & MK828707 & 100 & LC367596 & - & - & - & - \\
\hline A. sydowii & F18D & 97.34 & MK828706 & 97.34 & MK828706 & - & - & - & - \\
\hline P. citrinum & F19 & 99.27 & MK828711 & 99.63 & MG991339 & - & - & 99.27 & MK828711 \\
\hline P. citrinum & F19D & 99.54 & MK840969 & - & - & - & - & 99.27 & MK828711 \\
\hline $\begin{array}{l}P . \\
\text { simplicissimum }\end{array}$ & F23 & 98.93 & MK840973 & 99.02 & GU981631 & - & - & - & - \\
\hline $\begin{array}{l}P . \\
\text { simplicissimum }\end{array}$ & F23D & 99.27 & MK828712 & 99.32 & GU981632 & - & - & - & - \\
\hline
\end{tabular}

"-"denotes no clear PCR products were obtained using primers from Table 1 


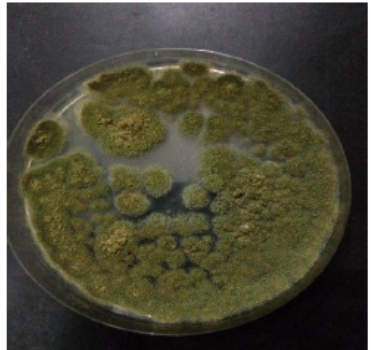

F1 (Aspergillus flavus)

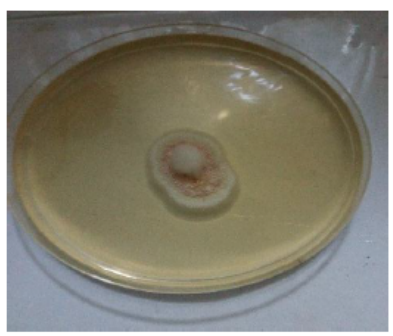

F6 (Aspergillus melleus)

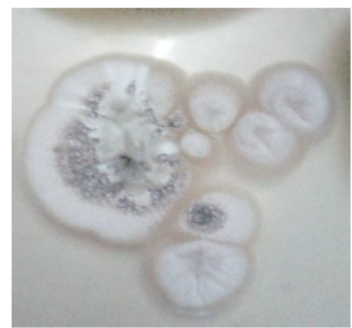

F12 (Penicillium shearii)

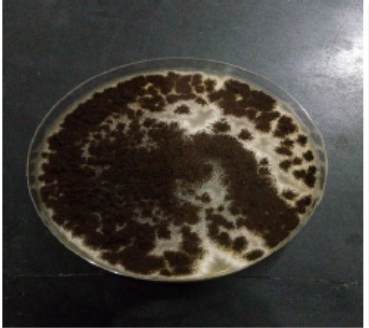

F10D (Aspergillus niger)

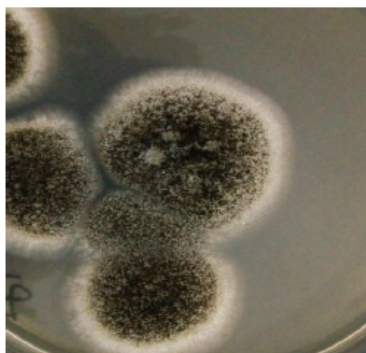

F2 (Apergillus japonicus)

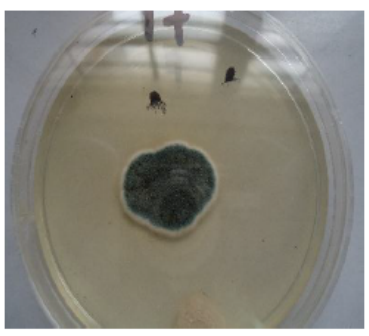

F7 Aspergillus sydowii

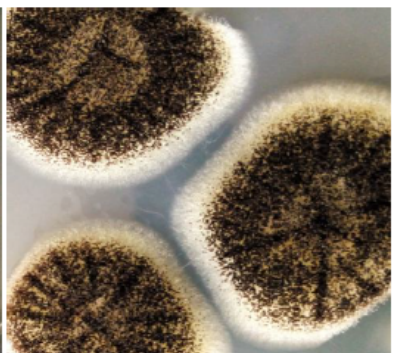

F3 (Aspergillus niger)

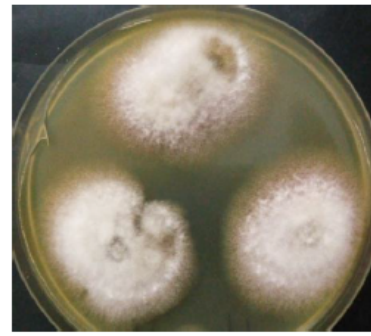

F8 (Fusarium incarnatum)

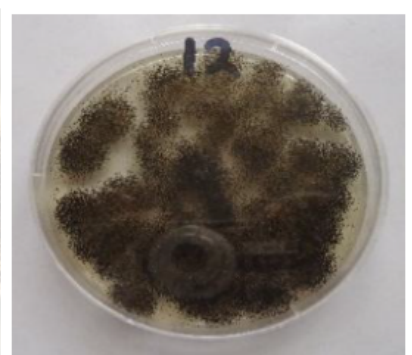

F5 (Aspergillus niger)

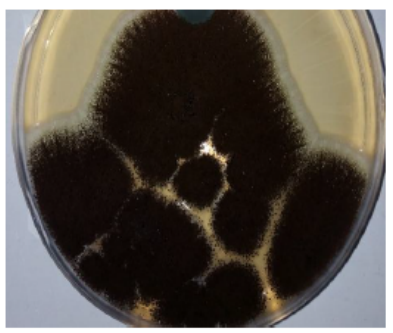

F10 (Aspergillus niger)

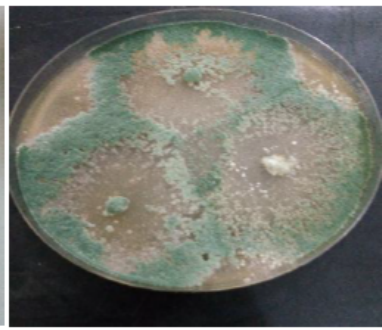

F13 (Trichoderma erinaceum)

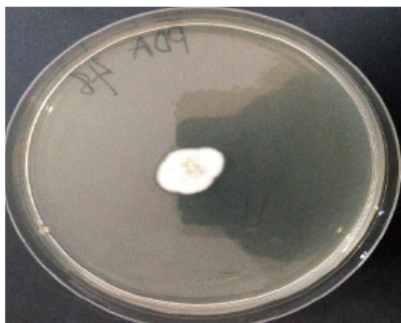

F18 (Aspergillus sydowii)

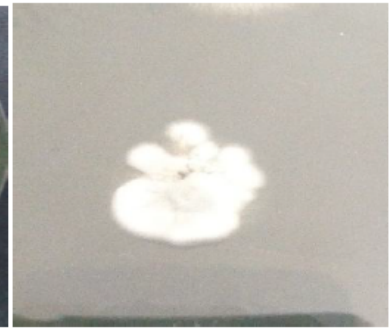

F14 (Aspergillus quadrilineatus)

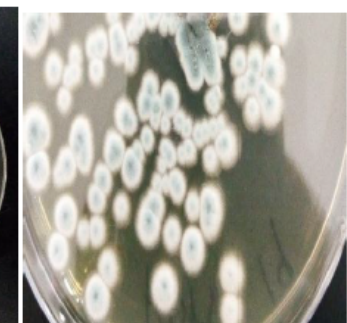

F19 (Penicillium citrinum)

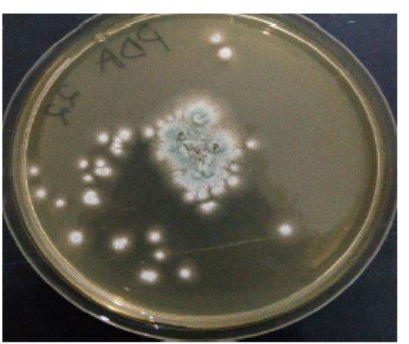

F16 (Aspergillus fumigatus)

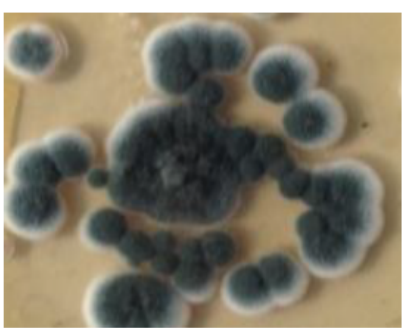

F23 (Penicillium simplicissimum)

\section{Figure 1}

(a): Cultural pictures of isolated fungi (b): Cultural pictures of isolated fungi 


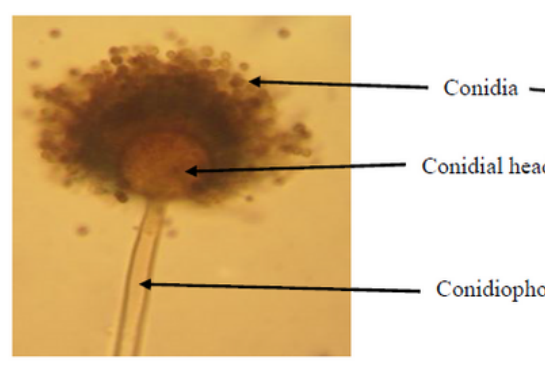

Aspergillus flavus

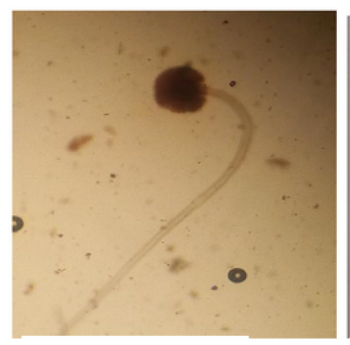

Aspergillus melleus

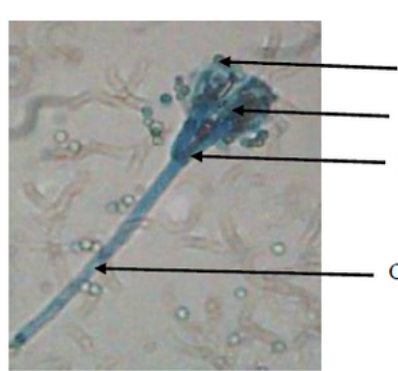

Penicillium citrinum

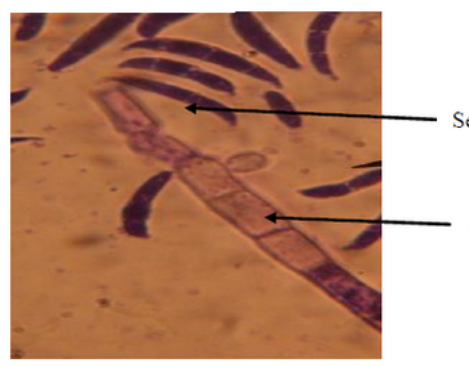

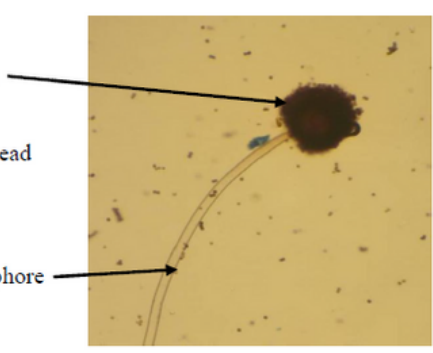

Aspergillus japonicus

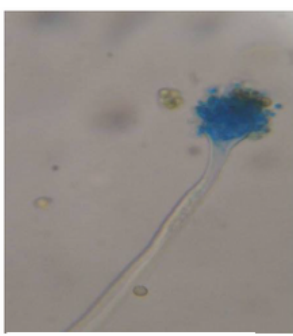

Aspergillus fumigatus

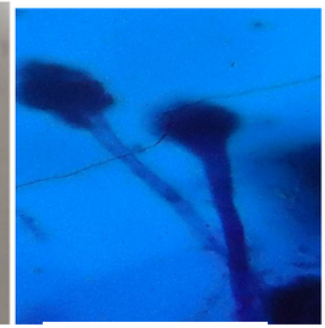

Aspergillus sydowii

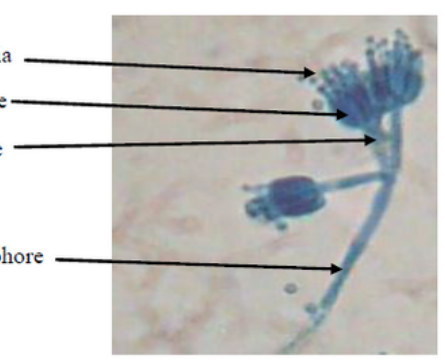

Penicillium shearii

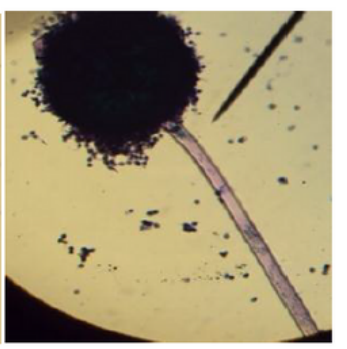

Aspergillus niger

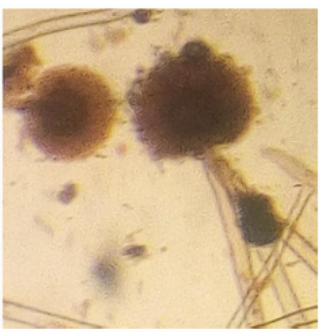

Aspergillus quadrilineatus

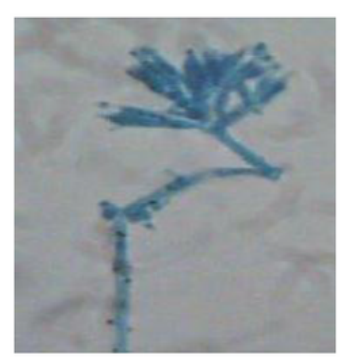

Penicillium simplicissimum

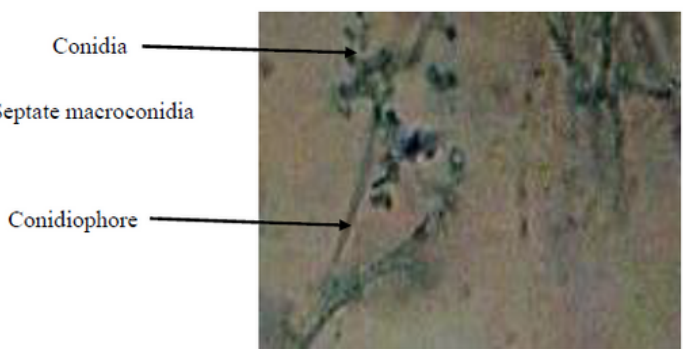

\section{Figure 2}

(a): Microscopic features of Aspergillus species (x40 magnification) (b): Microscopic features of Penicillium, Fusarium and Trichoderma species (x40 magnification) 


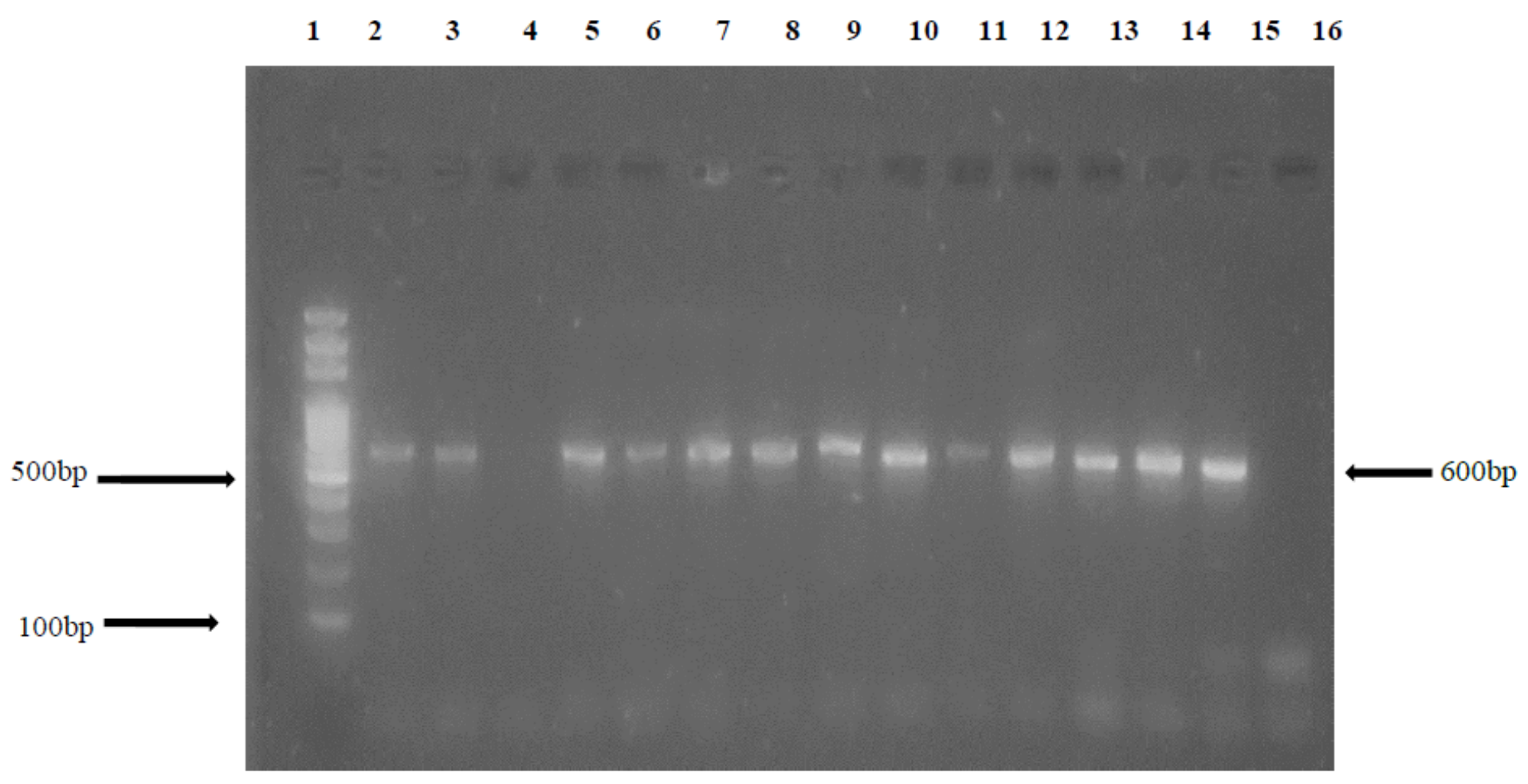

\section{Figure 3}

Agarose gel electrophoresis of PCR products amplified from genomic DNA of fungal isolates using ITS (ITS1-ITS4). Keys: Lane 1= 100bp solisbiodyne DNA Ladder; Lane 2 - Aspergillus flavus (F1); Lane 3=A. japonicus (F2D); Lane 4= A. niger (F3); Lane 5= A. niger (F5); Lane 6= A. melleus (F6); Lane 7= A. sydowii (F7); Lane 8=Fusarium incarnatum (F8); Lane 9= A. niger (F10); Lane 10= Penicillium shearii (F12); Lane 11=Trichoderma erinaceum (F13); Lane 12=A. quadrilineatus (F14); Lane 13= A. fumigatus (F16); Lane 14= A. sydowii (F18); Lane 15= Penicillium citrinum (F19); Lane 16= Penicillium simplicissimum (F23); bp= base pair; ITS=internal transcribed spacer region

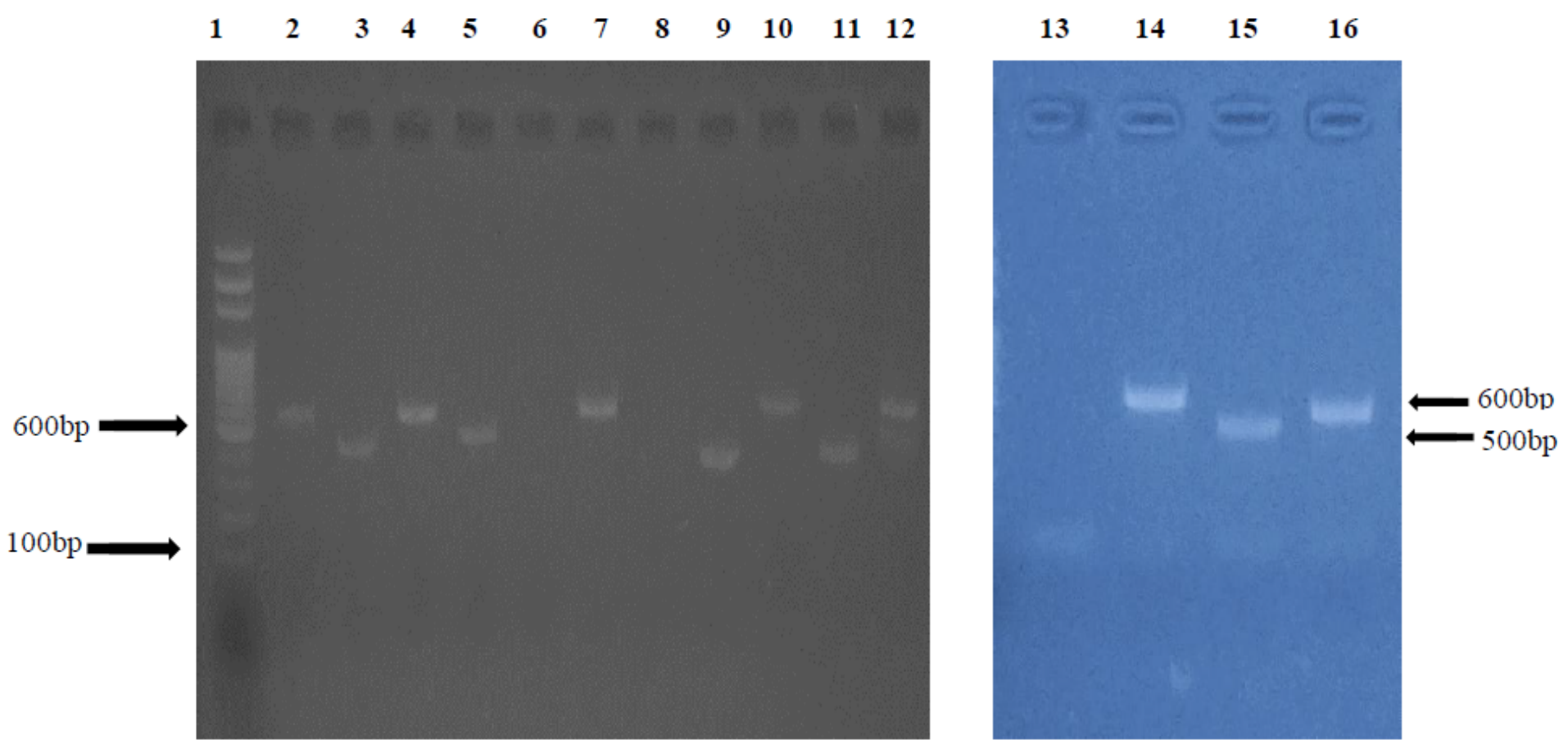

Figure 4 
Agarose gel electrophoresis of PCR products amplified from genomic DNA of fungal isolates using $\beta$-tubulin genes (Bt2a-Bt2b). Keys: Lane 1= 100bp solisbiodyne DNA Ladder; Lane 2=Aspergillus. flavus (F1); Lane 3=A. japonicus (F2D); Lane 4= A. niger (F3); Lane 5= A. niger (F5); Lane 6= A. melleus (F6); Lane 7= A. sydowii (F7); Lane 8=Fusarium incarnatum (F8); Lane 9= A. niger (F10); Lane 10= Penicillium shearii (F12); Lane 11=Trichoderma erinaceum (F13); Lane 12=A. quadrilineatus (F14); 13= A. fumigatus (F16); Lane 14= A. sydowii (F18); Lane 15= Penicillium citrinum (F19); Lane 16= Penicillium simplicissimum (F23); bp= base pair

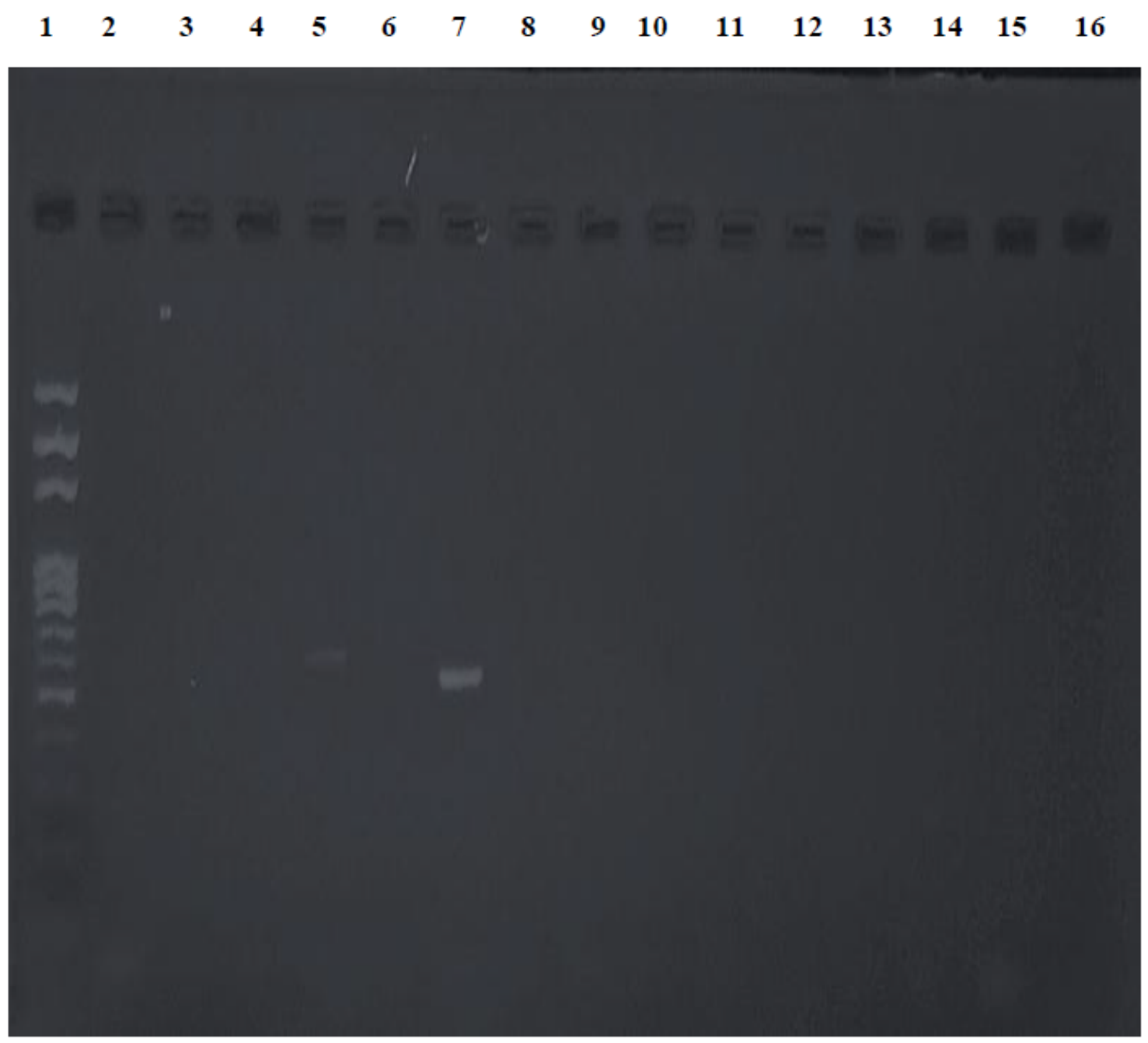

\section{Figure 5}

Agarose gel electrophoresis of PCR products amplified from genomic DNA of fungal isolates using RPB2 genes (5F-7CR). Keys: Lane 1 = 100bp solisbiodyne DNA Ladder; Lane 2= Aspergillus flavus (F1); Lane 3=Aspergillus japonicus (F2D); Lane 4=Aspergillus niger (F5D); Lane 5= Penicillium citrinum (F19); Lane 6= Penicillium shearii (F12); Lane 7= Penicillium citrinum (F19D); Lane 8= Aspergillus melleus (F6); Lane 9= Fusarium incarnatum (F8); Lane 10= Aspergillus niger (F10); Lane 11=Trichoderma erinaceum (F13); Lane 12= Trichoderma erinaceum (F13); bp = base pair, RPB2= RNA Polymerase II Second Largest Subunit 


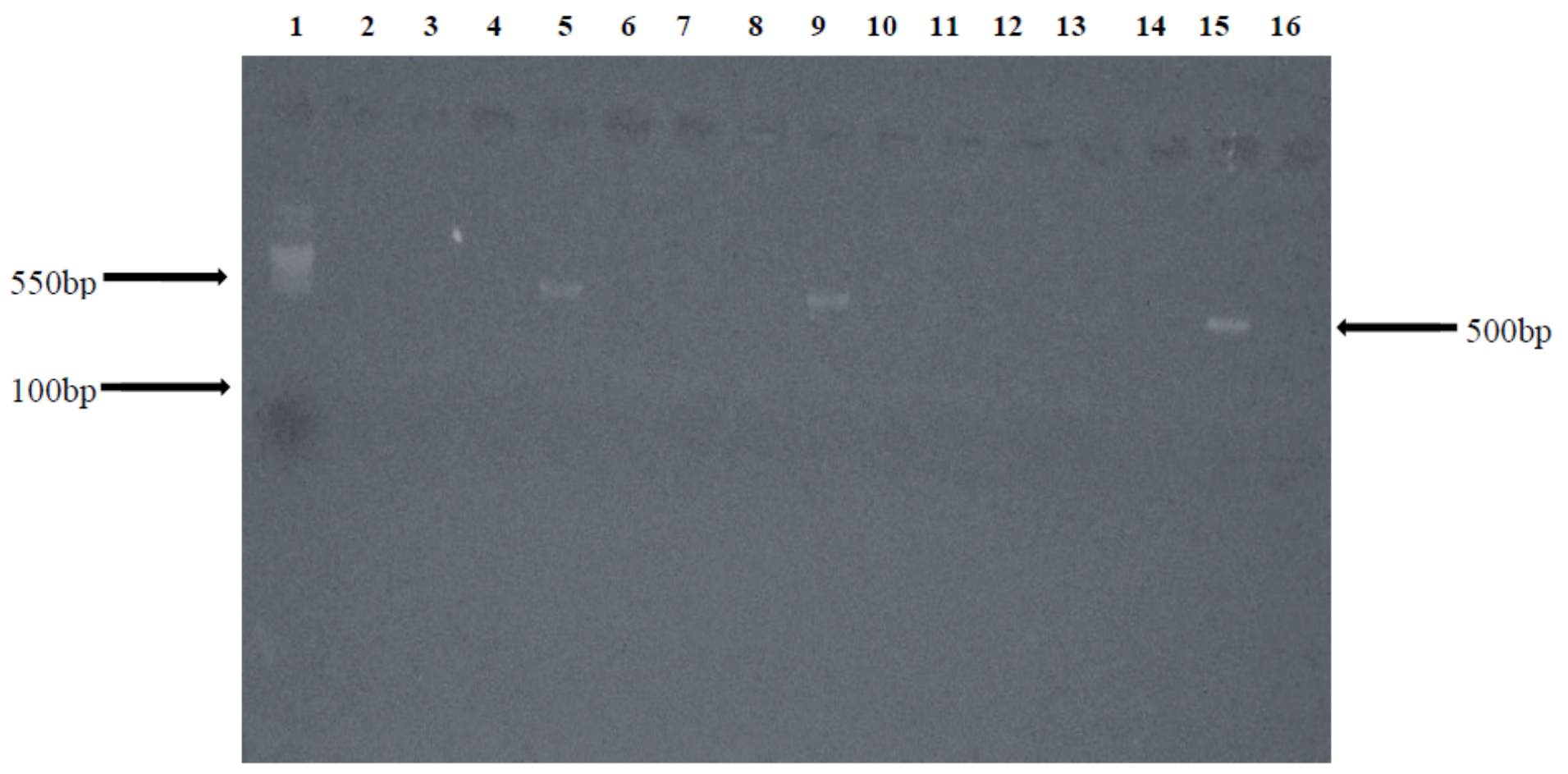

\section{Figure 6}

Agarose gel electrophoresis of PCR products amplified from genomic DNA of fungal isolates using calmodulin gene primers (CMD5-CMD6). Keys: Lane 1= 100bp solisbiodyne DNA Ladder; Lane 2 - Aspergillus flavus (F1); Lane 3=Aspergillus japonicus (F2D); Lane 4= Aspergillus niger (F3); Lane 5= Aspergillus niger (F5); Lane 6= Aspergillus melleus (F6); Lane 7= Aspergillus sydowii (F7); Lane 8=Fusarium incarnatum (F8); Lane 9= Aspergillus niger (F10); Lane 10= Penicillium shearii (F12); Lane 11=Trichoderma erinaceum (F13); Lane 12=Aspergillus quadrilineatus (F14); Lane 13= Aspergillus fumigatus (F16); Lane 14= Aspergillus sydowii (F18); Lane 15= Penicillium citrinum (F19); Lane 16= Penicillium simplicissimum (F23); bp= base pair 


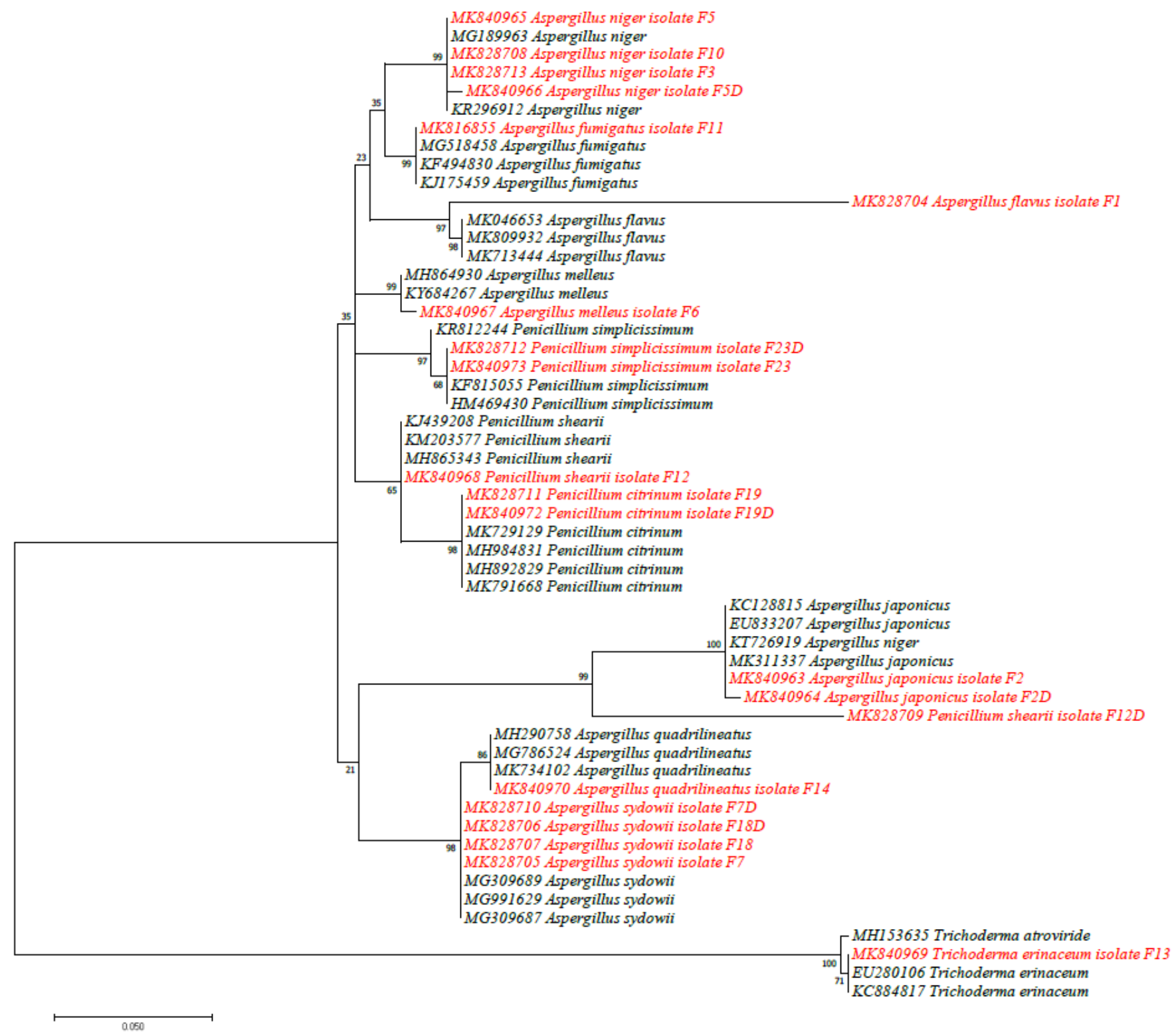

\section{Figure 7}

Phylogenetic tree of partial ITS gene sequences by maximum likelihood 


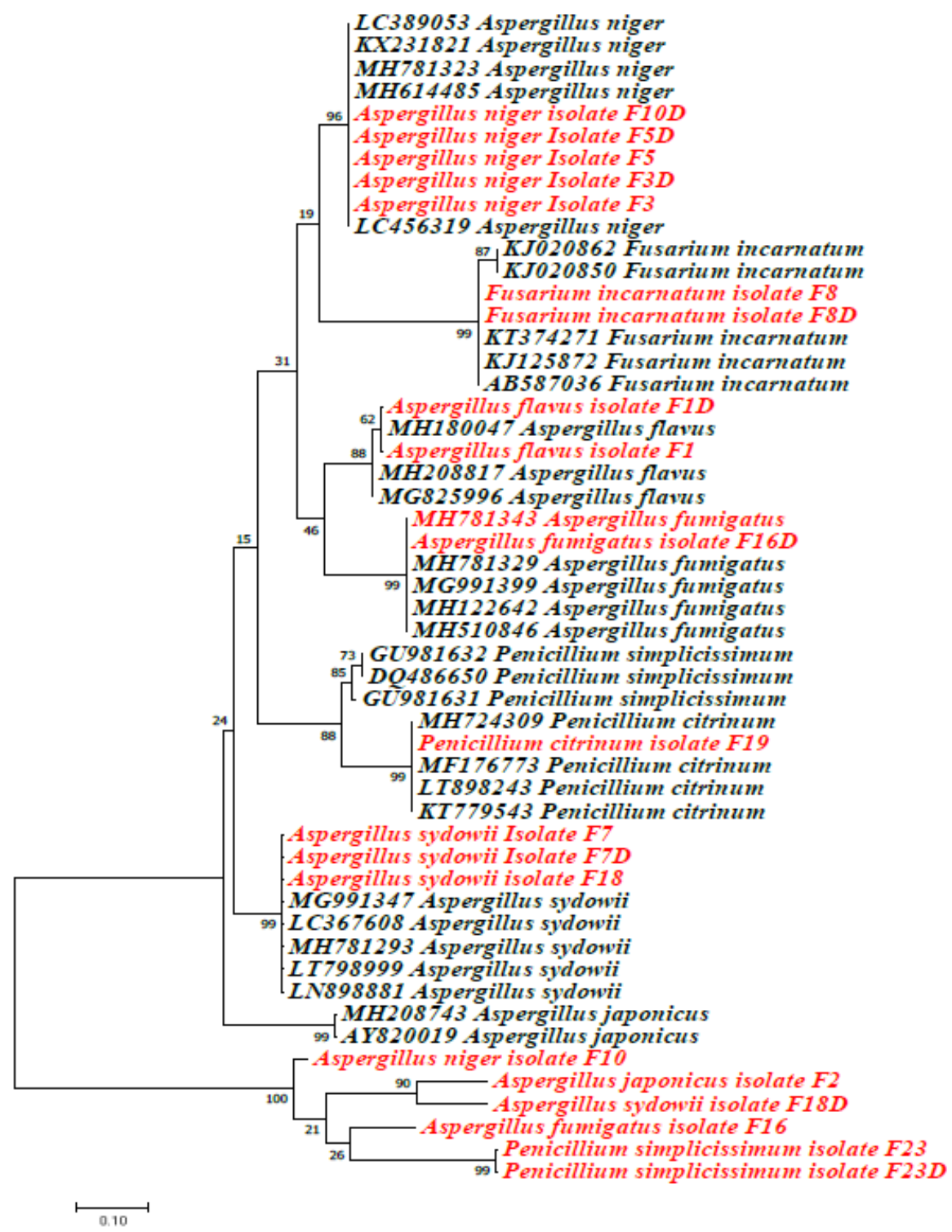

Figure 8

Phylogenetic tree of partial $\beta$-tubulin gene sequences by maximum likelihood 


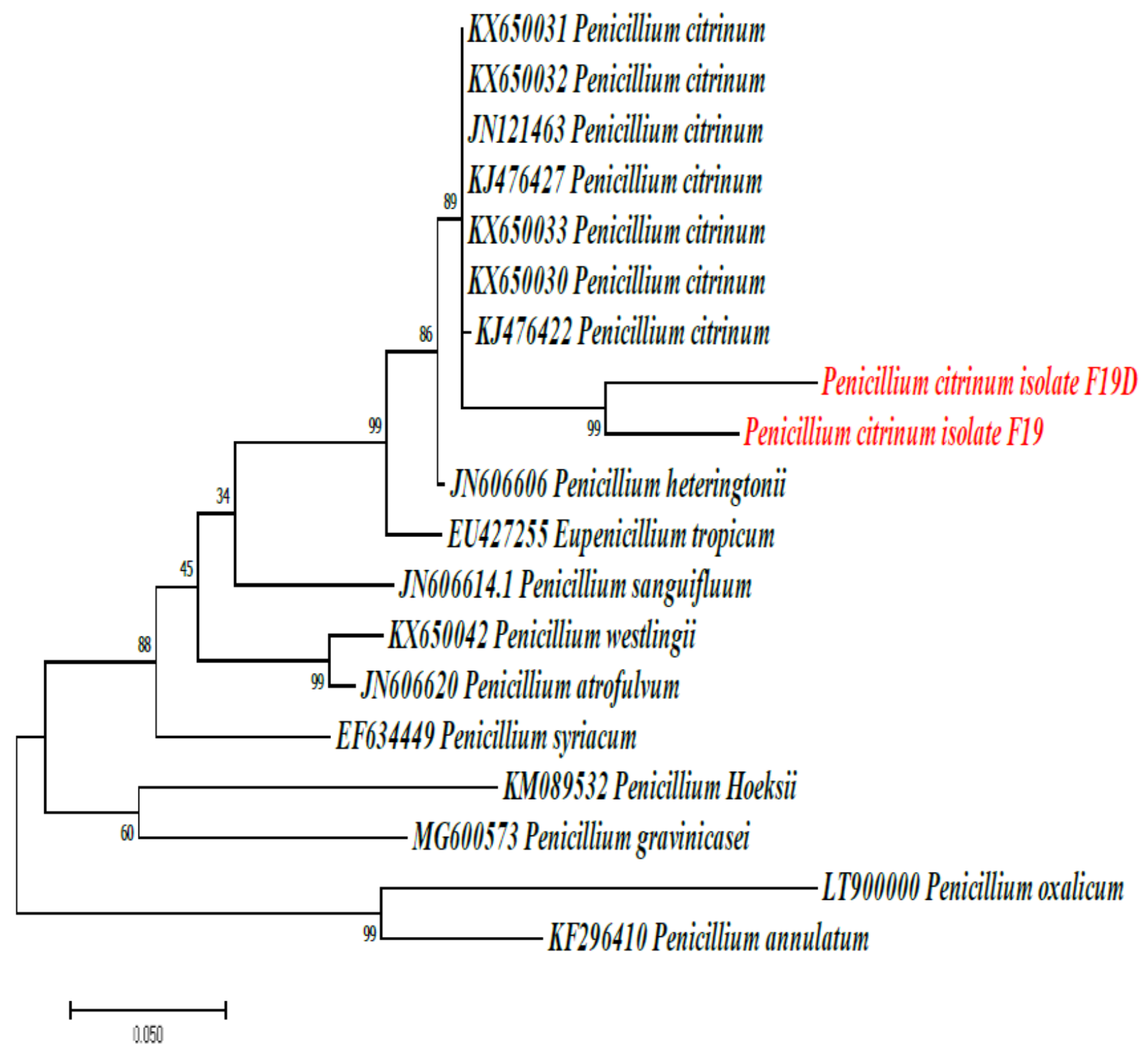

Figure 9

Phylogenetic tree of partial RPB2 gene sequences by maximum likelihood 


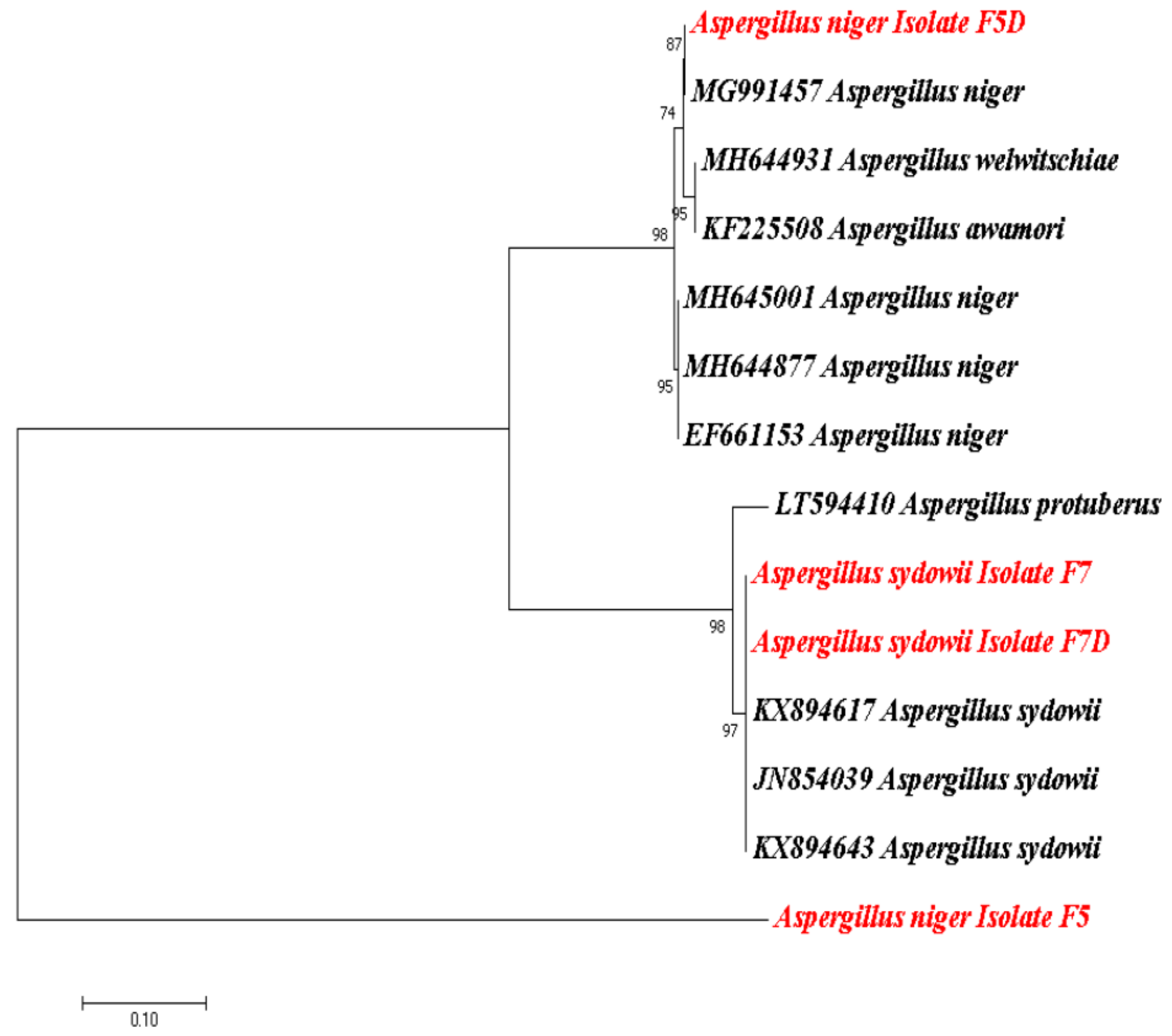

Figure 10

Phylogenetic tree of calmodulin gene sequences by maximum likelihood 